Research, part of a Special Feature on The influence of human demography and agriculture on natural systems in the Neotropics

\title{
Agricultural Abandonment, Suburban Growth, and Forest Expansion in Puerto Rico between 1991 and 2000
}

\author{
$\underline{\text { Isabel K. Parés-Ramos }}^{1}, \underline{\text { William A. Gould }}^{2}$, and $^{\text {T. Mitchell Aide }}{ }^{1}$
}

\begin{abstract}
The response of local economies to the globalization process can have a large effect on population and land-use dynamics. In countries with a high population density and relatively high levels of education, the globalization process has resulted in a shift in the local economy from agriculture to manufacturing, technology, and service sectors. This shift in the economy has impacted land-use dynamics by decreasing agricultural lands, increasing urban growth, and in some cases, increasing forest cover. This process of economic and forest transition has been well documented in Puerto Rico for the period 1950 to 1990, but some authors predicted that poor planning and continued urban growth would eliminate the gains in forest cover. To investigate the impacts of recent economic changes, we evaluated demographic and land-use changes for 880 "barrios" (i.e., neighborhoods), the smallest administrative unit, in Puerto Rico using government census data from 1990 and 2000 and land-cover classifications from 1991 and 2000. During this period, the population increased by 284127 people (8.2\%). Most of the growth was in the suburban barrios, whereas urban barrios lost population. This shift was reflected by the construction of more than 100000 housing units in suburban barrios. Although urban sprawl is perceived as the major land-cover change, urban cover only increased from $10 \%$ to $11 \%$ between 1990 and 2000, whereas the increase in forest cover was much greater (28\% to 40\%). Grasslands and shrublands were the major sources of new urban and forest areas in 2000. Although these results are encouraging in terms of increasing forest cover, most of the new development has been concentrated in the coastal plains, which are the location of most of the remaining agricultural areas, a few protected areas, and threatened ecosystems (e.g., mangroves).
\end{abstract}

Key Words: agriculture decline; forest expansion; forest transition; globalization; land use-cover change; suburban population growth; Puerto Rico

\section{INTRODUCTION}

Every phase of socioeconomic development has different effects on population and landscape dynamics. The transition from agricultural-based economies to manufacturing accelerated the urbanization process and the development of cities, often characterized by a monocentric urban growth pattern due to the concentration of industries, residences, and commerce in metropolitan areas (e. g., Mexico City, Sao Paulo, Buenos Aires, Beijing, London, New York) (Anas et al. 1998). Today, many societies worldwide are undergoing a major transformation from an industrial-based economy to a knowledge-based economy. These modern economies are based on the production, distribution, and use of information and technology, and are powered by high-tech industries that include electronics, pharmaceuticals, telecommunications, software development, and aerospace (Organisation for Economic Cooperation and Development (OECD) 1996). Along with these economic changes, innovations in information and communication technologies and the decentralization of commercial, industrial, and financial activities are also affecting the traditional patterns of urban agglomeration and driving new population and landscape dynamics (Elliot and Perry 1996, Munroe et al. 2005).

The effects of these modern socioeconomic trends include changes in the spatial structure of urban and rural areas, such as urban population decline, suburban growth, and the urbanization of rural areas (Munroe et al. 2005). In some developed countries, 
decentralization tendencies are stimulating urban sprawl and the conversion of agricultural lands and open spaces to urban land uses (Wassmer 2002). The loss of valuable agricultural lands is not only a response to urban expansion, but also reflects a decline in small-scale agricultural activities. In addition, the decline in agriculture jobs is furthered by the increase of employment opportunities in manufacturing, trade, tourism, and other service sectors, which attract more people, particularly the young and educated, to urban areas (Losada et al. 1998).

The ecological consequences of areas that have experienced rural-urban migration and agriculture abandonment have been documented for many developed countries, and often include an increase in forest cover (i.e., forest transition) (Rudel et al. 2002, Walker et al. 2002). More recently, similar patterns of forest or ecological transition have been documented in some developing countries including Costa Rica (Céspedes et al. 2003), Ecuador (Zahawi and Augspurger 1999, Rudel et al. 2002), Mexico (Klooster 2003, Read et al. 2003), Oceania (Endress and Chinea 2001), El Salvador (Hecht et al. 2006), and Puerto Rico (Aide et al. 1996, Grau et al. 2003, Lugo et al. 2004). But other studies have shown that different socioeconomic factors, such as a shift to large-scale agriculture, tree plantations or urban sprawl, could act as barriers for ecosystems recovery (Johnson 2001). The globalization process and the emergence of the knowledge-based economy are clearly affecting demographic and land-use dynamics globally, but understanding how these changes interact with local conditions is a major challenge for researchers, planners, and local governments.

\section{Globalization, Urban Growth, and Forest Recovery in Puerto Rico}

Puerto Rico is frequently used as an example of economic forest transition in a developing country where a change from agricultural to manufacturing and service sectors has stimulated forest recovery (Lugo et al. 1981, Birdsey and Weaver 1990, Thomlinson et al. 1996, Aide and Grau 2004, Helmer 2004). Most impressively, the island's forests have increased from approximately $6 \%$ to $40 \%$ between 1940 and 2000 while the population increased from approximately 2 to 4 million Franco et al. 1997, (Lugo 2002). Forest recovery in Puerto Rico has occurred mainly on abandoned pastures and agricultural lands, as a consequence of migration of rural population into urban areas in search of wage labor (Rivera and Aide 1998, Grau et al. 2003). Today, the growth of pharmaceutical and high-tech industries (Curcio 2005), the availability of higher-paying manufacturing jobs, and the decline of the agricultural sector (López et al. 2001) suggest that these factors will continue to be important socioeconomic drivers, but will forest cover continue to increase? Given that the population continues to grow, as has per capita income, there is an increasing demand for urban structures, particularly residential buildings. As in many developed countries, increasing purchasing power often translates into a migration from urban centers to suburban areas. In the case of Puerto Rico, researchers have predicted that this tendency of urban expansion will come at the cost of secondary forests (Thomlinson and Rivera 2000) and the remaining agricultural lands (López et al. 2001).

To understand how the globalization process (i.e., the shift from an agricultural economy to one highly dependent on manufacturing and service sectors) is affecting local population, urban development, and landscape dynamics, we analyzed demographic, housing, and land-use and land-cover changes for 880 "barrios" (i.e., neighborhoods) in Puerto Rico using government census data and land-cover classifications. Specifically, we addressed the following objectives: 1) describe the population dynamics and housing development patterns between 1990 and 2000, and 2) describe the landuse and land-cover changes between 1991 and 2000 to understand how population dynamics are affecting land-use practices. For both objectives, we were interested in understanding the patterns among barrios with different population densities (i.e., urban, suburban, rural), and in different geographical regions (i.e., coastal plains, coastal hills, central mountains).

\section{METHODS}

\section{Study Area}

Puerto Rico is located in the eastern part of the Caribbean and has an area of approximately 8900 $\mathrm{km}^{2}$, including Vieques and Culebra, two small island-municipalities located off the east coast. The altitude varies between sea level and $1300 \mathrm{~m}$, and the mean annual temperature ranges from $19^{\circ} \mathrm{C}$ to $26^{\circ} \mathrm{C}$. The ecological life zones of Puerto Rico 
include subtropical dry forests and subtropical rain forests, among other life zones described by Ewel and Whitmore (1973). In addition, the island can be divided into three major physiographic regions based on topographic features, geologic structure, and rock type: the coastal lowlands, the coastal hills, and the central mountains.

The population of Puerto Rico has increased from approximately 1 million in 1900 to 2 million in 1950 to 4 million in 2005. Since 1980, the annual growth rate has declined from $1.6 \%$ to less than $0.3 \%$ in 2007 (U.S. Census Bureau 2001). The island is divided into 78 municipalities, which are further subdivided into 900 neighborhoods or barrios. The area of the barrios ranges from $0.1 \mathrm{~km}^{2}$ (Barceloneta barrio-pueblo) to $64 \mathrm{~km}^{2}$ (Lapa barrio in Salinas). "Barrio-pueblo" refers to the main urban, commercial, and administrative center of each municipality. Although this project aims to provide a broad picture of the current population and landscape dynamics in Puerto Rico, we focused on the dynamics occurring at the barrio scale. The use of the barrio data, the smallest geographic unit, allowed us to accurately associate population changes with local changes in land-use and landcover patterns.

The geographical location of Puerto Rico and its political and economic relationship with the U.S. through a commonwealth association since 1952 have turned the island into an active participant in the global economy. Puerto Rico is an important production center for high-tech manufacturing and pharmaceutical production of international corporations such as Pfizer Inc., Abbott Laboratories, and Hewlett-Packard. In 2003, Puerto Rico shipped more than US $\$ 31$ billion worth of pharmaceutical products, making the island the world's largest international shipper of pharmaceutical products, with a $24.5 \%$ share of the total world shipments (Curcio 2005). In addition to the pharmaceutical companies operating in Puerto Rico (e.g., Johnson and Johnson, Merck, GlaxoSmithKline, Warner Chilcott, Clariant, and AstraZeneca), many biotech companies (e.g., Amge, Eli Lilly) and high-tech and software companies (e.g., Siemens, General Electric, Solectron, Smart Modular, CutlerHammer, Microsoft, Storage Technology, and Hubbell) have also made major investments in the island.

\section{Census Data and Geographic Trends of Population Growth and Distribution}

Population and housing data of the 900 barrios of Puerto Rico were obtained from the U.S. 1990 and 2000 Censuses of Population. Cartographic reference maps from the U.S. Census Bureau's spatial database (Topologically Integrated Geographic Encoding and Referencing system-TIGER) were used to establish the political boundaries of the 900 barrios. Between 1990 and 2000, the political boundaries of six barrios changed and land-cover data for the two island-municipalities of Vieques ( $n$ $=8$ barrios $)$ and Culebra $(n=6$ barrios) were incomplete, thus these 20 barrios were excluded from the analysis. The remaining 880 barrios comprise $98 \%\left(8607 \mathrm{~km}^{2}\right)$ of the total main-island land area. For the geographical analysis of population growth and distribution, we used a digital elevation map (DEM) (Gould et al. 2005) to divide the island landscape into three major regions: coastal plains, coastal hills, and central mountains. ESRI's ArcGIS $®$ version 9 GIS software was used to manage all data, and to perform spatial analyses of the demographic and land-cover information.

To analyze temporal population dynamics and the spatial distribution of the population in Puerto Rico, we classified the 880 barrios into rural, suburban, or urban following Martinuzzi et al. (2007) and based on density data for 1990 and 2000 (Fig. 1a). Rural barrios had a population density less than 200 people $/ \mathrm{km}^{2}$ Suburban barrios from 200-1000 people $/ \mathrm{km}^{2}$, and Urban barrios greater than 1000 people $/ \mathrm{km}^{2}$. These categories are similar to those used in other demographic studies (Bolioli 2001) and a population classification analysis based on patterns of urban development and census data of Puerto Rico in 2000 (Martinuzzi et al. 2007). For the geographical analysis of population growth and distribution, we used a DEM (U.S. Geological Survey 2005). Each of the 880 barrios was assigned to an elevation region including "coastal plains" $(0-$ $100 \mathrm{~m})$, "coastal hills" (100-250 m), and the "central mountains" (> $250 \mathrm{~m}$ ) (Fig. 1b). Population and housing data for 1990 and 2000 were analyzed based on barrio classification and elevation features to identify landscape patterns of population growth and distribution. 
Fig. 1. Maps of Puerto Rico showing a) the 900 barrios classified by population density in 1990 into three classes (i.e., rural, suburban, urban), b) the three elevation regions, and c) land-use categories (modified from Gould et al. 2007).

(a) 1990 Barrio classification

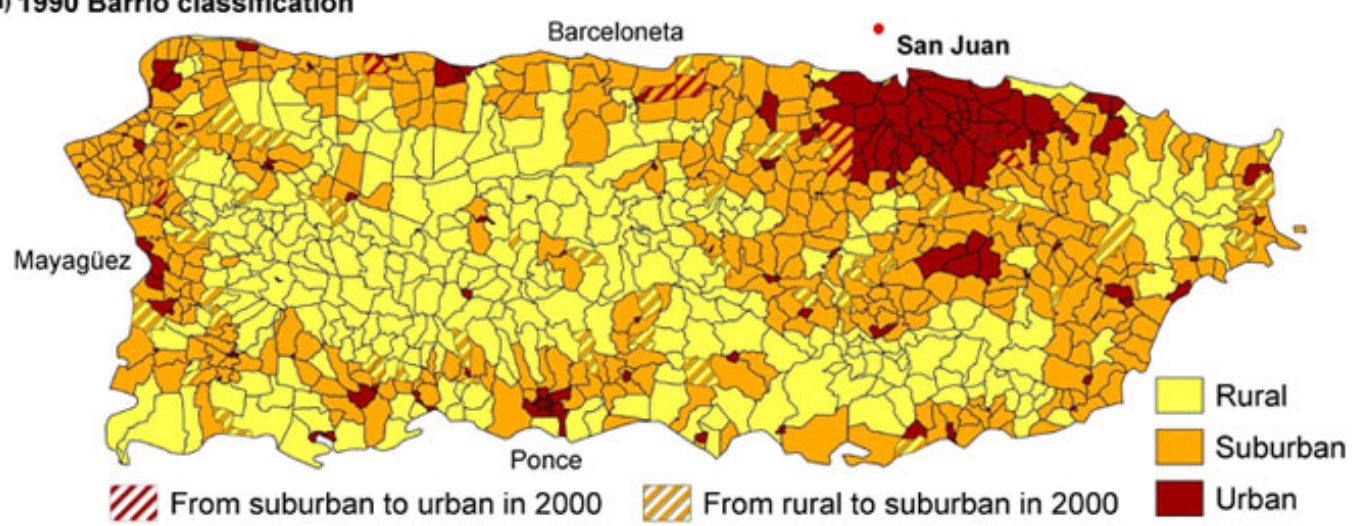

(b) Elevation regions and Protected areas

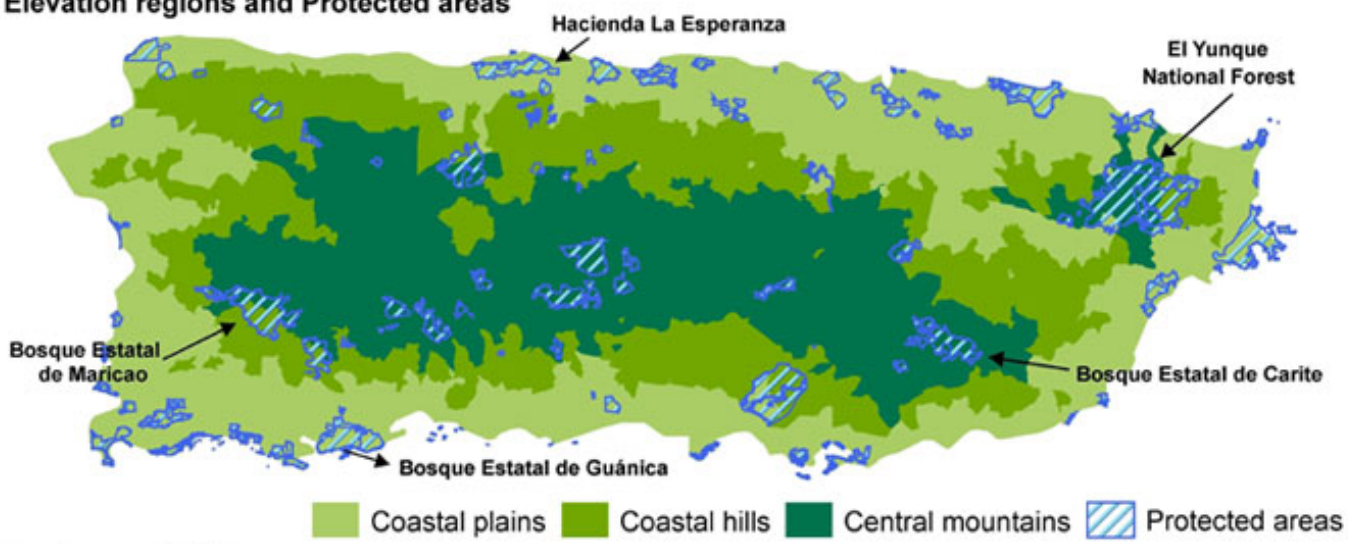

(c) Land cover 2000

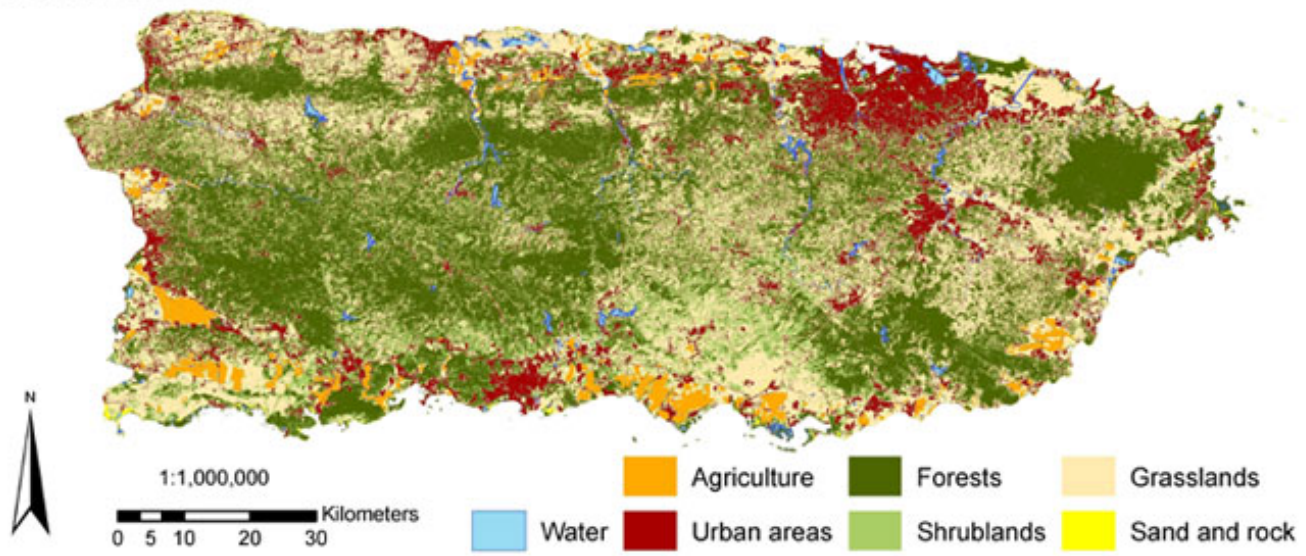




\section{Analysis of Land-Cover Change between 1991 and 2000}

For the temporal and spatial analysis of land-use and land-cover changes from 1991 to 2000, we used two digital land-cover maps of the island. The map of 1991 was a satellite-image-based map of the land cover for 1991-1992 with a 30-m resolution that included 26 land-cover and woody vegetation classes (Helmer et al. 2002). The 2000 land cover was developed by the Puerto Rico Gap Analysis Program (Gould et al. 2007) and is based on 15-m resolution Landsat ETM+ satellite imagery acquired between 2001 and 2003, and included 70 land-cover classes. Key differences between these maps include inconsistencies between years in classifying forest vs. woodland and shrubland, in classifying woodland and shrubland vs. grassland, and in delineating urban areas. The 1991 classification overestimated urban areas relative to the 2000 classification. The finer resolution of the 2000 classification resulted in areas of residential development (i.e., houses surrounded by vegetation) being more precisely delineated, reducing the mapped amount of developed area. To minimize differences in classification schemes, both classifications were resampled to $15-\mathrm{m}$ resolution and reduced to six broad categories of land cover: forest, shrubland, grassland, agriculture, urban, and sand and rock (Appendix 1, Fig. 1c). Given that the area in sand and rock was less than $1 \%$, this category was excluded from the analyses. A transition matrix analysis was used to identify island-wide land-cover changes.

At the barrio level, we conducted Non-metric Multidimensional Scaling (NMS) to compare landcover change between 1991 and 2000. The analysis was done using PC ORD 5 and following the recommendations of McCune and Grace (2002). The NMS ordination grouped barrios based on percentage cover of the five different land-cover types. To perform these analyses we used the Sørensen index to create the distance matrix, a random starting configuration with a maximum of six axes, a stability criterion $=5 \times 10^{-5}, 50$ permutations with real data, and a Monte Carlo test based on 50 permutations. The final solution was determined by a combination of results from the Monte Carlo test, and the minimum number of dimensions that provided the lowest stress and instability (McCune and Grace 2002). Each barrio was assigned to one of nine categories based on its population density (urban, suburban, rural) in 1990 and location (coastal plains, coastal hills, central mountains). These data were used to create a secondary matrix. The initial ordination included all barrios in both years $(n=1760)$. The average value (i.e., ordination location) of the barrios in each the nine density/location categories was calculated for both years to show the overall trend in land-use change.

\section{RESULTS}

\section{Population and Housing Dynamics}

Of the 880 barrios in 1990, 375 barrios (43\%) were classified as suburban barrios, $360(41 \%)$ as rural barrios, and $145(16 \%)$ as urban barrios (Fig. 1a, Table 1). In 1990, approximately $46.6 \%$ of the population lived in urban barrios, but by 2000 , the percentage of people living in urban areas decreased to $42.7 \%$, and the suburban barrios became the most populated areas of the island (Table 1). Between 1990 and 2000, the total population of urban barrios decreased by 12137 people, whereas suburban and rural barrios increased by 235348 and 60916 people, respectively (Table 1). Although the suburban barrios had the largest population increase, between 1990 and 2000, only seven suburban barrios converted to urban, compared with 45 rural barrios that converted to suburban (Fig. 1a), suggesting that the movement of population into rural areas is also a significant dynamic occurring in the island.

This island-wide pattern is clearly represented by the population change at the barrio-level (Fig. 2). Twenty-two of the 23 barrios $(96 \%)$ that lost more than 1000 people between 1990 and 2000 were urban barrios, whereas 76 of the 94 barrios $(81 \%)$ that increased by more than 1000 people were either suburban or rural barrios. Urban population decline was most noticeable in the barrio-pueblos, the urban center of each municipality. Seventy of the 78 barrio-pueblos $(90 \%)$ had negative population growth, accounting for a loss of over 25000 urban inhabitants. These demographic changes were accompanied by the construction of over 200000 new housing units between 1990 and 2000, and the rate of increase of new houses was much greater $(19.9 \%)$ than population growth $(8.2 \%)$ (Table 1$)$. More than $50 \%$ of the new housing units were built in suburban barrios, in particularly in the coastal plains (Table 1). In addition, more than 60000 new households were built in urban barrios in the coastal 
Table 1. Population and housing dynamics between 1990 and 2000 in Puerto Rico based on barrio type and elevation regions

\begin{tabular}{|c|c|c|c|c|c|c|c|c|c|c|c|}
\hline \multirow[b]{2}{*}{$\begin{array}{l}\text { Barrio type and } \\
\text { Elevation region }\end{array}$} & \multirow[t]{2}{*}{$\begin{array}{c}\mathrm{n} \\
\text { barrios }\end{array}$} & \multicolumn{2}{|c|}{$\begin{array}{c}\text { Population in } \\
1990\end{array}$} & \multicolumn{2}{|c|}{$\begin{array}{c}\text { Population in } \\
2000\end{array}$} & \multicolumn{2}{|c|}{ Population change } & \multicolumn{2}{|c|}{$\begin{array}{c}\text { New households } \\
\text { units }\end{array}$} & \multicolumn{2}{|c|}{ People/housing units } \\
\hline & & number & $\%$ & number & $\%$ & number & $\%$ & number & $\%$ change & 1990 & 2000 \\
\hline Urban & 145 & 1614644 & 46.6 & 1602507 & 42.7 & -12137 & -0.8 & 69668 & 12.0 & 3.17 & 2.81 \\
\hline Coastal plains & 121 & 1462310 & 42.2 & 1449918 & 38.7 & -12392 & -0.8 & 63162 & 12.1 & 3.15 & 2.79 \\
\hline Coastal hills & 14 & 113112 & 3.3 & 115676 & 3.1 & 2564 & 2.3 & 5702 & 13.7 & 3.44 & 3.09 \\
\hline Central mountains & 10 & 39222 & 1.1 & 36913 & 1.0 & -2309 & -5.9 & 804 & 3.5 & 2.94 & 2.67 \\
\hline Suburban & 375 & 1416001 & 40.8 & 1651349 & 44.0 & 235348 & 16.6 & 108842 & 30.1 & 3.91 & 3.51 \\
\hline Coastal plains & 204 & 826946 & 23.9 & 972120 & 25.9 & 145174 & 17.6 & 63873 & 29.3 & 3.79 & 3.45 \\
\hline Coastal hills & 115 & 396690 & 11.4 & 459200 & 12.2 & 62510 & 15.8 & 30486 & 31.3 & 4.07 & 3.59 \\
\hline Central mountains & 56 & 192365 & 5.5 & 220029 & 5.9 & 27664 & 14.4 & 14483 & 31.2 & 4.15 & 3.61 \\
\hline Rural & 360 & 436250 & 12.6 & 497166 & 13.3 & 60916 & 14.0 & 30467 & 23.2 & 3.58 & 3.31 \\
\hline Coastal plains & 73 & 104857 & 3.0 & 122720 & 3.3 & 17863 & 17.0 & 7667 & 23.3 & 3.38 & 3.21 \\
\hline Coastal hills & 110 & 141247 & 4.1 & 165403 & 4.4 & 24156 & 17.1 & 10907 & 27.3 & 3.66 & 3.37 \\
\hline Central mountains & 177 & 190146 & 5.5 & 209043 & 5.6 & 18897 & 9.9 & 11893 & 20.1 & 3.65 & 3.34 \\
\hline TOTAL: & 880 & 3466895 & 100 & 3751022 & 100 & 284127 & 8.2 & 208977 & 19.9 & 3.49 & 3.15 \\
\hline
\end{tabular}

plains despite considerable population loss (Table 1). This increase in housing in all three barrio types reduced the people:housing unit ratio from 3.49 in 1990 to 3.15 in 2000 (Table 1).

Geographic location also played an important role in population change (Table 1, Fig. 2). The coastal plains region had the largest increase in the number of people and housing units between 1990 and 2000, gaining more than 150000 people and over 130000 new households (Table 1, Fig. 2). But, based on the percentage of population change, the coastal hills region had the highest growth with a $13.7 \%$ change, followed by the central mountains region $(10.5 \%)$ and the coastal plains $(6.3 \%)$. Moreover, a spatial analysis of population growth based on elevation range showed a rapidly growing suburban population in every elevation region, although the largest increase was in the coastal plains (Table 1, Fig. 2). Rural barrios also showed a population increase in the three regions, similar to the percentage change in suburban barrios, whereas the populations of urban barrios are declining in the coastal plains and central mountains, and only slightly growing in the coastal hills (Table 1).

\section{Land-Cover Changes between 1991 and 2000}

At the island-wide scale, there has been an increase in urban cover (10.5\% to $11.3 \%$ ) and a large increase in forest cover (28.2\% to 39.7\%) (Fig. 3, Table 2). Between 1991 and 2000, urban cover increased by $68 \mathrm{~km}^{2}$, and this development was concentrated in suburban barrios and in the coastal plains region. The source of these new urban and forests areas in 2000, were mainly the other land-use classes, which all declined: grasslands $(37.7 \%$ to $32.9 \%)$, shrublands (17.3\% to $12.7 \%)$, and agriculture $(6 \%$ to $3.1 \%$ ) (Fig. 3, Table 2). The major sources of new 
Fig. 2. Population change between 1990 and 2000 for the three barrio types within the three elevation regions.

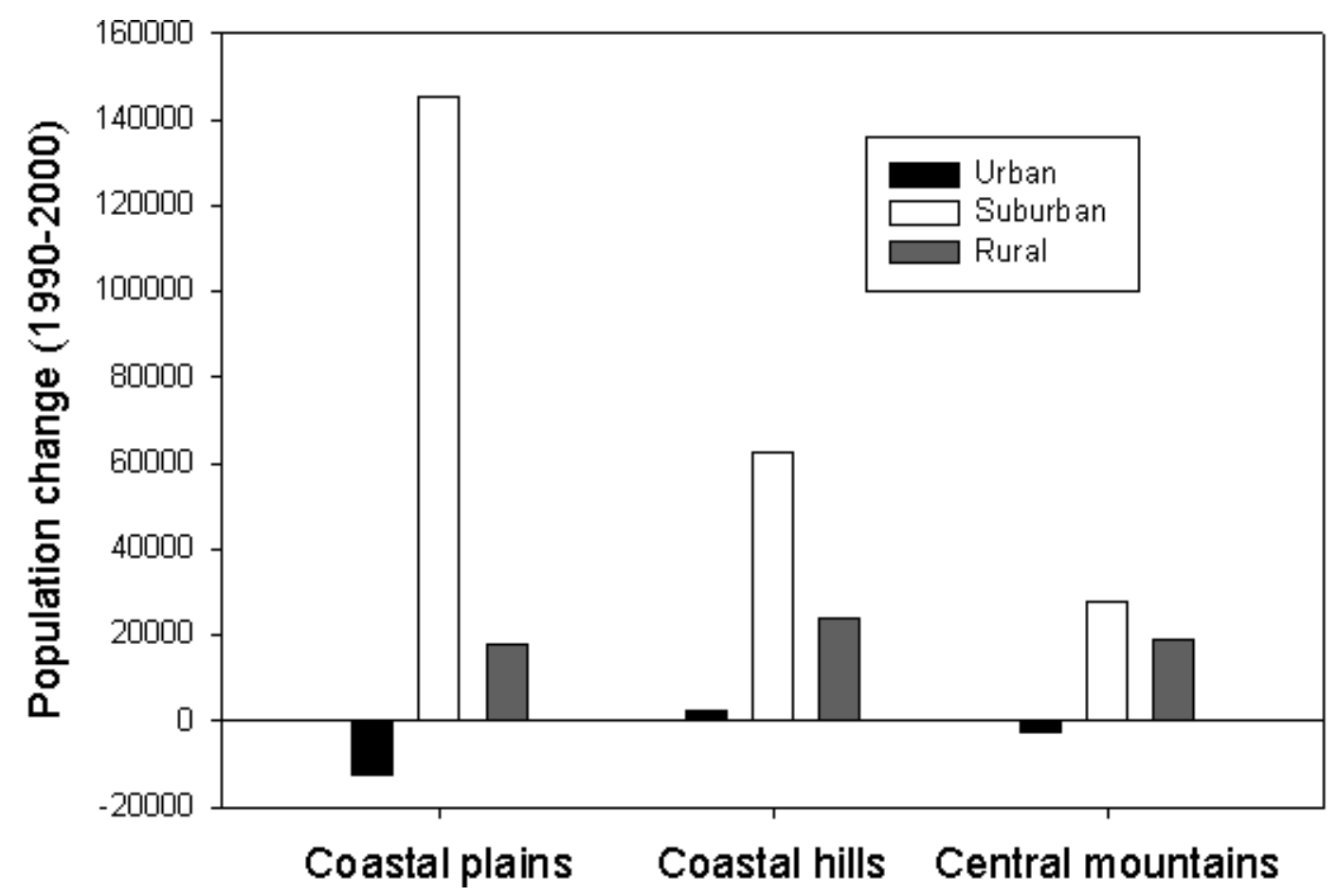

forests were shrublands $\left(810 \mathrm{~km}^{2}\right)$ and grassland $\left(668 \mathrm{~km}^{2}\right)$, whereas the major source of urban development was grasslands $\left(302 \mathrm{~km}^{2}\right)$ (Table 2). Agricultural cover declined by approximately $50 \%$ (Fig. 3), and most of these abandoned areas converted into grasslands (Table 2). An example of these dynamics is shown in Fig. 4, where there has been urban expansion, agricultural abandonment (to the north of the urban center), and the conversion of grasslands and shrublands to forest cover. The land-cover transition matrix also showed that some urban land converted to other cover types (Table 2). Of the more than $900 \mathrm{~km}^{2}$ classified as urban in 1990, approximately $226 \mathrm{~km}^{2}$ were classified as grasslands in 2000. The possible causes of this unlikely transition are discussed in more detail below.

Barrios varied greatly in land cover (Fig. 5a). In the NMS analysis, the major factors that separated the barrios along axis 1 were forest $(r=-0.48)$ and grassland cover $(r=0.75)$. Axis 2 separated the barrios mainly based on forest $(r=-0.84)$ and urban $(r=0.63)$ cover (Fig. 5b). When barrios were grouped into nine population density/location classes, there was a clear separation of groups based on population density. The urban barrios, regardless of location, presented similar land-use composition (low grasslands, high urban). The three suburban barrios classes were also very similar, and were characterized by a high proportion of grasslands (Fig. 5b). The rural barrios in the hills and mountains grouped together with high proportions of forest and grasslands, but the coastal rural barrios were more similar to the suburban barrios with a greater proportion of urban cover (Fig. 5b). Similar to the island-wide statistics (Fig. 2, Table 2), between 1991 and 2000 the nine barrio population density/ location classes showed a decline in grassland cover and a large increase in forest cover (Fig. 5b). 
Fig. 3. Percentage land-use change at the island-wide scale.

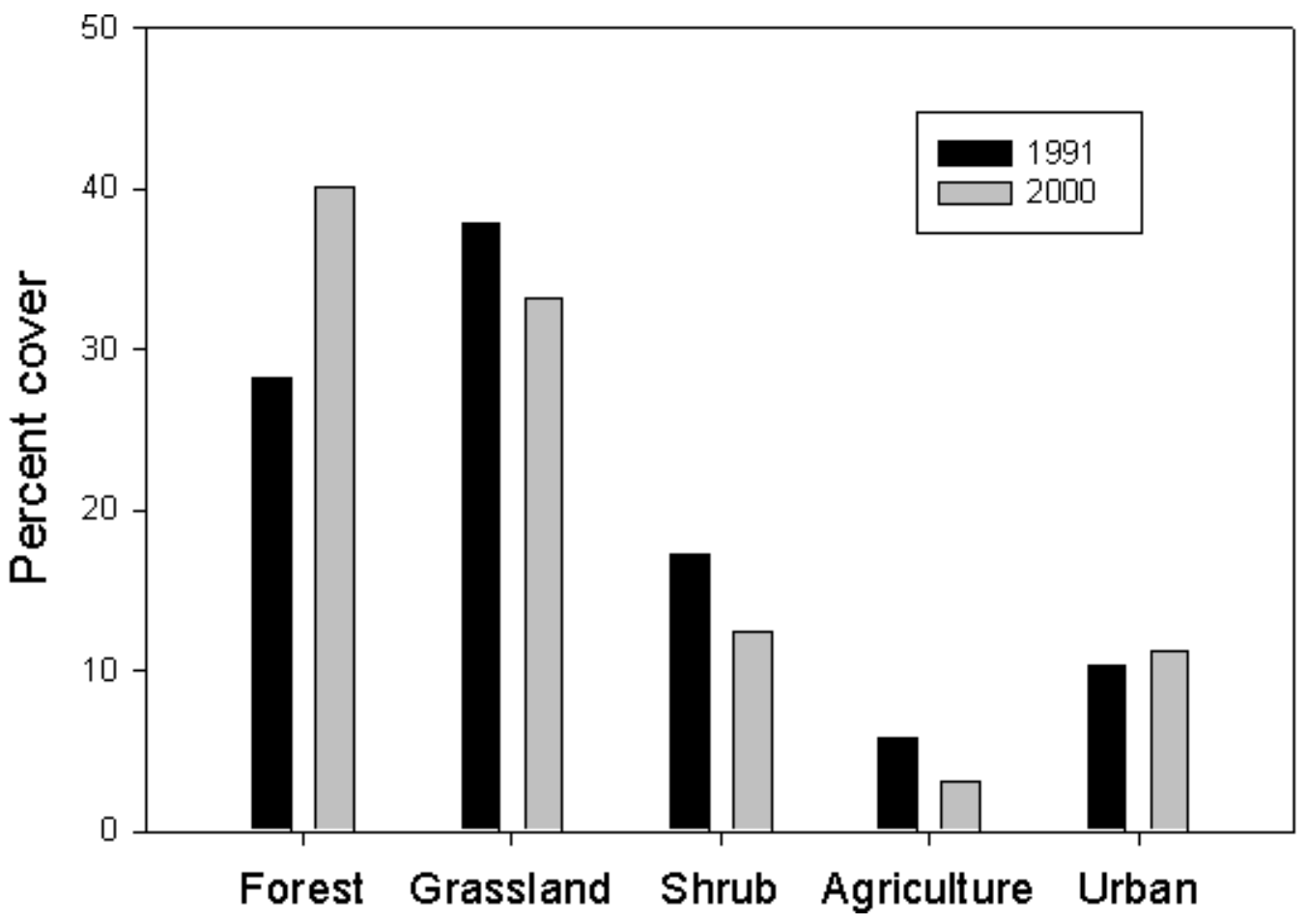

\section{DISCUSSION}

\section{Population Dynamics—the Suburbanization Process}

From 1990 to 2000, population dynamics in Puerto Rico were defined by rapid suburban population growth and a significant depopulation of the major urban centers of the island. The considerable increase in population and housing construction in suburban barrios reflects a growing trend of urbansuburban migration, particularly to the outskirts of the San Juan Metropolitan Area. Part of this increase was due to the exodus from the main urban centers, particularly the barrio-pueblos. Approximately $90 \%$ of the barrio-pueblos lost population (>25 000) between 1990 and 2000. In addition, the conversion of 45 rural barrios into suburban barrios between 1990 and 2000 (Fig. 1a) suggests a strong preference for less densely populated areas, despite the high availability of housing units (i.e., new and vacant houses) in urban areas, is also contributing to the rapid suburbanization of the rural landscape. The extensive road network throughout Puerto Rico, advances in communication technology, lower suburban house prices, and the expansion of the industrial area outside the major urban centers are the most important factors contributing to this suburbanization process.

Suburbanization is often visualized as one of the stages of the urban development process, along with urbanization, counterurbanization (i.e., urban to rural) and reurbanization, based on population growth and decline in the core and periphery of metropolitan regions (van den Berg et al. 1982). Usually, urbanization and reurbanization phases are related to the "concentration hypothesis," whereas suburbanization and counterurbanization are related to the "dispersion hypothesis" (Elliot and Perry 1996). During the urbanization phase, the loss of jobs in the agricultural sector due to industrialization leads to migration of rural population towards the inner-city, resulting in urban-metropolitan agglomerations (Elliot and Perry 1996). In Puerto Rico, rural-urban migration was the most prevalent population dynamic as the 
Table 2. Transition matrix analysis of land-cover changes in Puerto Rico from 1991 to 2000

\begin{tabular}{|c|c|c|c|c|c|c|c|c|c|}
\hline \multirow{2}{*}{\multicolumn{2}{|c|}{$\begin{array}{l}\text { Land Cover } \\
\text { 1991-2000 }\end{array}$}} & \multirow{3}{*}{$\begin{array}{r}\text { Grassland } \\
1736.1\end{array}$} & \multirow{3}{*}{$\begin{array}{l}\text { Forest } \\
668.5\end{array}$} & \multicolumn{2}{|c|}{2000} & \multirow{3}{*}{$\begin{array}{r}\text { Agriculture } \\
64.6\end{array}$} & \multirow{3}{*}{$\begin{array}{r}\text { Sand \& } \\
\text { Rock }\end{array}$} & \multirow{3}{*}{$\begin{array}{r}\begin{array}{r}\text { Total Area } \\
\mathrm{km}^{2} \text { in } 1991\end{array} \\
3246.7\end{array}$} & \multirow{3}{*}{$\begin{array}{r}\text { Percentage } \\
\text { in } 1991 \\
37.7\end{array}$} \\
\hline & & & & \multirow{2}{*}{$\begin{array}{r}\text { Shrubland } \\
469.1\end{array}$} & \multirow{2}{*}{$\begin{array}{l}\text { Urban } \\
302.2\end{array}$} & & & & \\
\hline 1991 & Grassland & & & & & & & & \\
\hline & Forest & 287.2 & 1815.8 & 260.6 & 46.9 & 11.5 & 3.0 & 2424.9 & 28.2 \\
\hline & Shrubland & 349.3 & 810.5 & 270.2 & 58.7 & 4.5 & 1.5 & 1494.5 & 17.3 \\
\hline & Urban & 226.6 & 72.8 & 62.4 & 534.6 & 5.2 & 4.7 & 906.4 & 10.5 \\
\hline & Agriculture & 227.0 & 46.4 & 30.9 & 30.1 & 177.2 & 0.7 & 512.3 & 6.0 \\
\hline & Sand \& Rock & 6.0 & 2.9 & 1.6 & 2.1 & 0.4 & 9.6 & 22.6 & 0.3 \\
\hline Total & Area $\mathrm{km}^{2}$ in 2000 & 2832.2 & 3416.9 & 1094.8 & 974.6 & 263.3 & 25.7 & 8607.4 & 100 \\
\hline Perce & tage in 2000 & 32.9 & 39.7 & 12.7 & 11.3 & 3.1 & 0.3 & & \\
\hline
\end{tabular}

economy shifted from agriculture to manufacturing in the 1950s and following decades. Today, the island is going through the suburbanization phase, which is characterized by economic restructuring processes, decentralization of employment and services, higher urban land prices, and the availability of jobs in small and medium cities causing population and household movements away from the urban centers (Elliot and Perry 1996).

Our study also revealed that counterurbanization is also occurring in Puerto Rico, referring to the movement of people outside urban areas, but specifically into rural areas, resembling a reversal of the urbanization process. In Puerto Rico, these counterurbanization trends can be observed mainly on the west coast of the island, particularly in the municipalities of Arecibo, Isabela, and Cabo Rojo, as well as in the island's municipalities of Vieques and Culebra. These population dynamics could be associated with amenity migration to the coastal countryside, with tourism, recreation, and more specifically, with the establishment of second homes. In addition, patterns of rural development can also be observed in the surroundings of the San Juan Metropolitan Area and near areas of recent industrial development (e.g., pharmaceuticals and biotechnology companies), in the municipalities of
Santa Isabel, Guayama, Las Piedras, and Aguas Buenas. This type of development, or "edge cities," with low-density residential, commercial, and industrial development has greatly expanded the most populous metropolitan areas of the U.S. (e.g., New York, Los Angeles, Philadelphia, and Atlanta). A similar process of urban depopulation and suburban growth is occurring in China, particularly in and around the Beijing metropolitan area (Zhou and Ma 2000). A major driver of these changes has been foreign investments, which have stimulated modernization and regional industrial growth (Shenjing et al. 2006). These socioeconomic changes have also caused suburban expansion in China due to industrial decentralization, transportation improvements, and new housing construction in the suburbs (Zhou and Ma 2000), similar to the dynamics we have observed in Puerto Rico.

\section{Land-Use Dynamics-Increasing Urban and Forest Cover}

Between 1991 and 2000, landscape dynamics in Puerto Rico were characterized by a large increase in forest cover accompanied by urban expansion, and a decrease in grassland and agriculture. Although there has been a considerable growth in 
Fig. 4. Land-cover changes between 1991 and 2000 around the city of Mayagüez in western Puerto Rico.
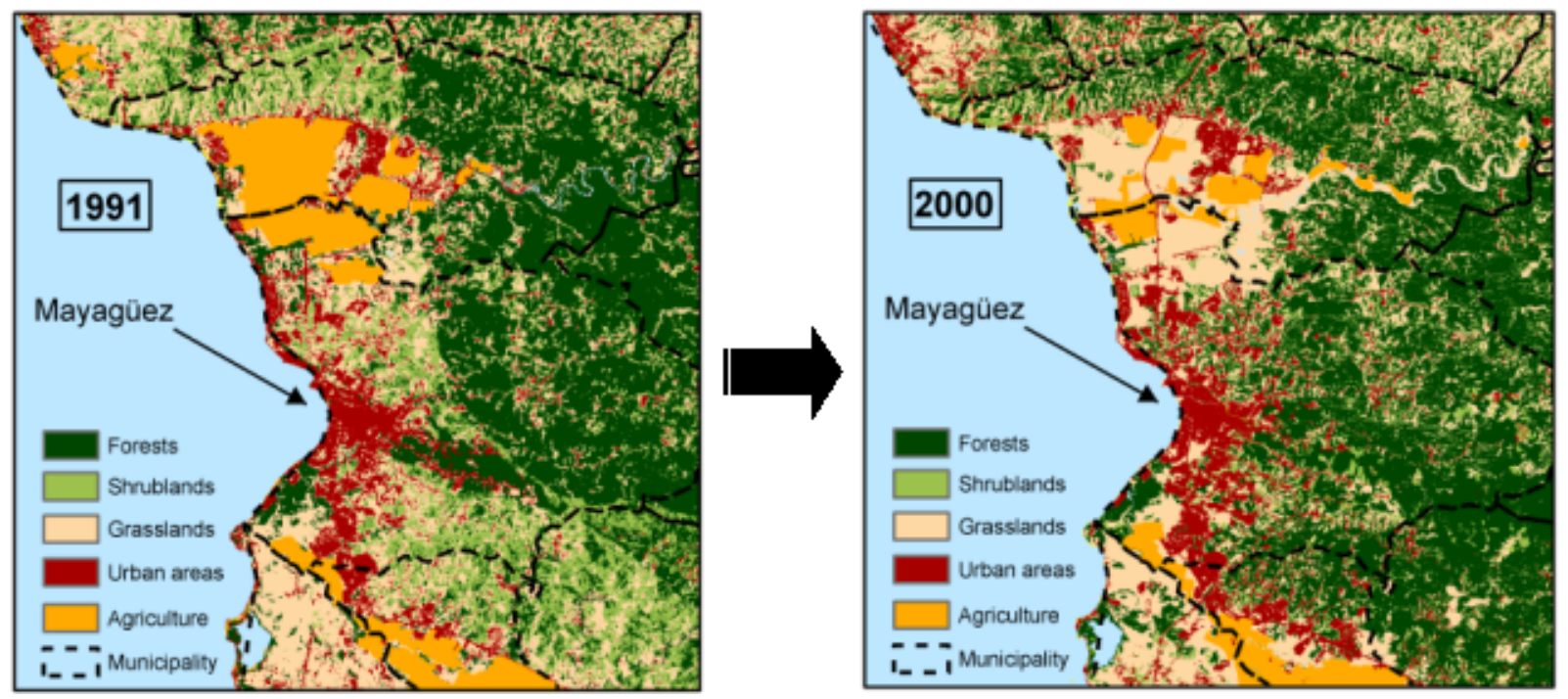

the suburban and rural populations of the island, urban cover only increased by $7 \%$, while forest cover increased by $41 \%$ (Fig. 3, Table 2). The landcover matrix analysis (Table 2) showed a conversion of urban areas to other land-cover types between 1991 and 2000. These unlikely transitions probably occurred because developed (i.e., urban) pixels tend to occur in small patches formed by mixed pixels that include grasslands and forested areas. Minor shifts in the registration of the imagery can lead to misaligned pixels and artificial transitions from urban to forest or grasslands. Although this is a problem at small spatial scales, our estimates of urban land-cover change are consistent with those reported by Helmer and Ruefenacht (2005) in their change detection analysis of urban cover in Puerto Rico for 1991 and 2000 using cloud-free satellite images.

Most new urban development occurred in areas classified as grasslands in 1991, whereas only a small portion of forested areas $(5 \%)$ and agricultural lands $(3 \%)$ were converted to urban cover (Table 2). Martinuzzi et al. (2007) reported that nearly $60 \%$ of all the urban land uses in Puerto Rico in 2000 corresponded to relatively high-density developments. A major factor that could be driving these changes is the high cost of land in Puerto Rico. By 2000, the median housing value in Puerto Rico reached US\$75 100, an increase of $107 \%$ since 1990 when the median value was US\$36 200. In general, population densities in Puerto Rico are higher than in cities in the United States (U.S. Census Bureau 2001), but urban densities on the island are far lower than the world average (Demographia World Urban Areas 2007). This indicates that urban areas have been underutilized at the expense of open space for housing and development. Furthermore, the construction of approximately 200000 new housing units plus the accompanying roads and commercial areas has occurred primarily at the expense of open space as opposed to increasing density of urbanized areas.

Between 1991 and 2000, the area of agriculture cover decreased by approximately $50 \%$, from 512 $\mathrm{km}^{2}$ in 1991 to $263 \mathrm{~km}^{2}$ in 2000 . The majority of agricultural lands in 1991 (more than 44\%) were converted to grassland by 2000 , whereas less than $10 \%$ of the total agricultural lands were converted to urban land uses. The decline in agricultural production in Puerto Rico is associated with high costs of production, low productivity, and growth of non-farm jobs (López et al. 2001). The abandonment of agriculture has been the major process that has permitted natural forest expansion 
Fig. 5. NMS ordination based on the percentage of land cover for each barrio in 1991 and 2000. a) all barrios from $1991(n=880)$. The symbol legend is in panel b; b) trends in land-cover change based on the mean of the $\mathrm{x}$ and $\mathrm{y}$ values of barrios in each population density/location class for 1991 (colored symbols) and 2000 ( O).

a)

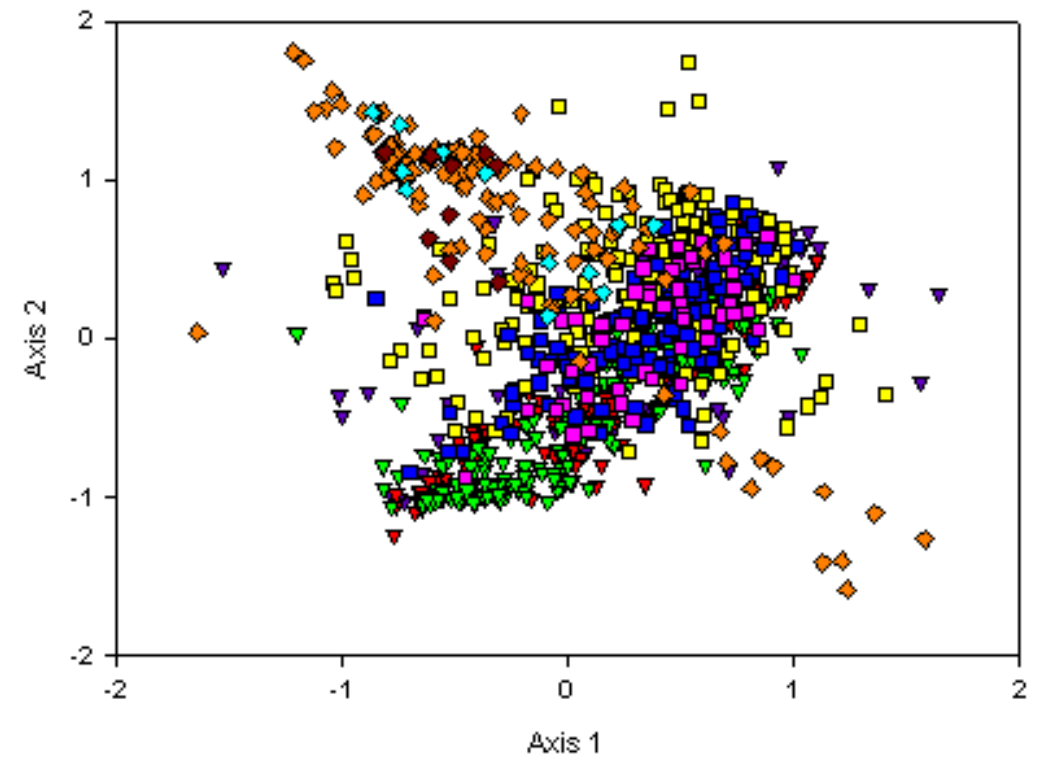

b)

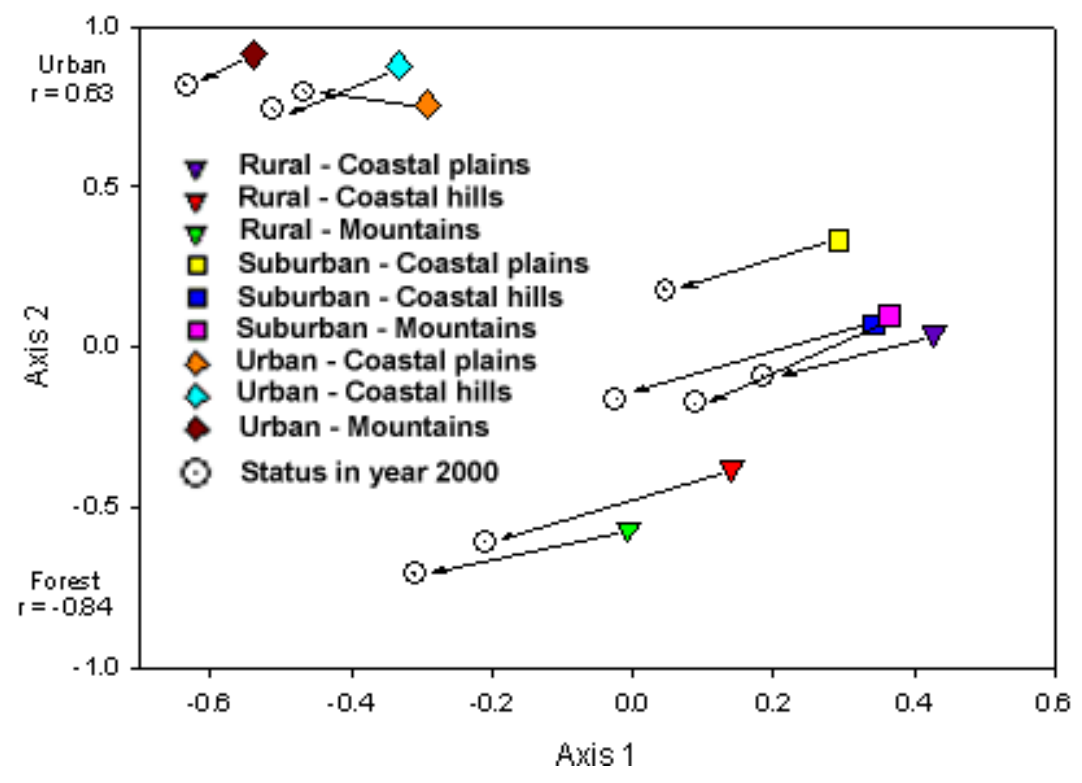


in Puerto Rico at the same time that population and urban cover are increasing. Although most of the increase in forest cover between 1991 and 2000 was due to the natural regrowth of secondary forest in shrublands and grasslands (Table 2), most of these areas were previously agricultural lands that were abandoned over the last 50 years, and are in the process of secondary succession (Aide et al. 2000). In the past, most forest regrowth occurred in the central mountains, but our barrio-level analysis showed that forest cover is increasing in all barrio types despite their geographic location (Fig. 5).

\section{CONCLUSIONS}

Between 1990 and 2000 in Puerto Rico, suburbanization trends and natural forest regrowth were the most important population and landscape dynamics. In Puerto Rico, the transition to a knowledge-based economy has caused socioeconomic changes, such as an increasing demand for employment in the manufacturing, technology, and service sectors, and the decentralization of commercial and financial activities. This decentralization tendency is mainly in response to the emergence of new industrial areas outside the main urban center, the San Juan Metropolitan Area, and is probably the most important factor influencing suburban growth and urban depopulation on the island. A consequence of this economic growth has been an increase in per capita income, which as in other parts of the world, has led to urbansuburban migration (Kahn 2000). Suburban population growth in Puerto Rico has also been greatly facilitated by the extensive road network that makes it possible to easily commute from one region of the island to other, but this factor has also had negative impacts on the environment (Martinuzzi et al. 2007). More than $99 \%$ of the island area is located within $1 \mathrm{~km}$ of the nearest road (Grau et al. 2004), encouraging urban sprawl throughout the island landscape and causing the reduction of open spaces, fragmentation of habitats, increase in energy consumption, greater air and water pollution and almost total reliance on the automobile for transportation (Martinuzzi et al. 2007). In fact, in 1990 , only $10.3 \%$ of the total population in Puerto Rico used public transportation to get to work, and by 2000 , it decreased to $5.3 \%$ (U.S. Census Bureau 2001).

Due to the limited land availability on the island, and in order to prevent further urban sprawl, it would be useful if Puerto Rico entered the reurbanization phase, with migration back to urban centers. This phase tends to occur in post-industrialized countries in response to successful restoration projects in the inner city and a shift in preference for a urban lifestyle. But in Puerto Rico, urban depopulation, also known as the shrinking city phenomenon (Banzhaf et al. 2005), continues to be a challenge for urban and regional planners, scholars, policy makers, and citizens. The challenges they face include revitalizing decaying and abandoned structures, maintaining an aging infrastructure, providing adequate public services, and encouraging new business activities and employment opportunities (Sánchez and Dawkins 2001). Investments in urban infrastructure renewal and smart growth strategies, such as increasing green areas and providing a variety of transportation options, are some alternatives that could reduce urban depopulation and help prevent urban sprawl.

In terms of landscape dynamics, forested areas in Puerto Rico are increasing due to the natural regrowth of secondary forest in shrublands and grasslands throughout the island.

Although these results are encouraging in terms of increasing forest cover, agriculture in Puerto Rico is disappearing (Table 2). In addition, most new urban development has been concentrated on the coastal plains, which are where most of the remaining agricultural lands and few protected areas are located (Fig. 1b). More than 2.5 million people live on the coastal plains, and uncontrolled developments in this region will not only eliminate the last agricultural lands (López et al. 2001), but may also have negative impacts on adjacent wetlands and coastal ecosystems (Gould et al. 2007). In Puerto Rico, as well as other countries that have experienced agricultural decline, mountainous regions with steep slopes are often the first areas that are abandoned and often return to natural vegetation with little or no intervention (Aide et al. 2000, Grau and Aide 2007). In fact, during the 1990 s, $38 \%$ of the world's countries experienced sustained increases in forest cover (Rudel et al. 2005), after a decrease in agriculture production. Rudel et al. (2005) refer to this sequence of events as the "economic development path" to forest transition. Population and land-use dynamics between 1990 and 2000 in Puerto Rico occurred in the virtual absence of landscape planning, suggesting that minor intervention (e.g., promoting greater vertical development) could result in a much more efficient use of the land resources. 
Responses to this article can be read online at:

http://www.ecologyandsociety.org/vol13/iss2/art1/responses/

\section{Acknowledgments:}

This research was supported in part by an institutional grant from FIPI program of the University of Puerto Rico, Rio Piedras Campus and National Science Foundation (DEB-0731594, EF-0709598) to TMA and by the USDA Forest Service International Institute of Tropical Forestry Puerto Rico Gap Analysis Project (06IA-11120101-006-USGS-BRD). We thank Maya Quiñones, Michael Jiménez, Mariano Solórzano, Olga Ramos, Gary Potts, and Carlos Zambrana for theirtechnical assistance and Sebastián Martinuzzi, Ricardo Grau, and two anonymous reviewers for comments on the manuscript.

\section{LITERATURE CITED}

Aide, T. M., and H. R. Grau. 2004. Globalization, migration, and Latin American ecosystems. Science 305:1915-1916. [online] URL:

http://tcel.uprrp.edu/articulos/Aide\%20and\%20Grau\% 202004.pdf.

Aide, T. M., J. K. Zimmerman, J. Pascarella, J. Marcano-Vega, and L. Rivera. 2000. Forest regeneration in a chronosequence of tropical abandoned pastures: implications for restoration ecology. Restoration Ecology 8:328-338. [online] URL: http://tcel.uprrp.edu/articulos/Aide,\%20T.M. \%20et\%20al.\%202000.pdf.

Aide, T.M., J. K. Zimmerman, M. Rosario, and H. Marcano. 1996. Forest recovery in abandoned cattle pastures along an elevational gradient in northeastern Puerto Rico. Biotropica 28:537-548. [online] URL: http://tcel.uprrp.edu/articulos/Aide, \% 20T.M.\%20et\%20al.\%201996.pdf.

Anas, A., R. Arnott, and K. A. Small. 1998. Urban spatial structure. Journal of Economic Literature 36:1426-1464.

Banzhaf, E., and A. Kindler. 2005. Land use changes and population development in shrinking urban regions-exemplified on the City of Leipzig, Germany. Pages 43-48 in Y. Himiyama, A. Mather,
I. Bicik, E. V. Milanova, editors. Land use/cover changes in selected regions in the world. Volume IV. International Geographical Union Commission on Land Use / Cover Change (IGU-LUCC) Research Reports.

Birdsey, R. A., and P. L. Weaver. 1990. Forest resources of Puerto Rico. U.S. Forest Service Resources Bulletin SRS-22. [online] URL: http://w ww.srs.fs.usda.gov/pubs/rb/rb srs022.pdf.

Bolioli, T. 2001. The population dynamics behind suburban sprawl. Dissertation. Center for Environmental Studies, Brown University, Providence, Rhode Island, USA.

Céspedes, M., M. V. Gutierrez, N. M. Holbrook, and O. J. Rocha. 2003. Restoration of genetic diversity in the dry forest tree Swietenia macrophylla (Meliaceae) after pasture abandonment in Costa Rica. Molecular Ecology 12:3201-3212.

Curcio, J. C. 2005. Inteco propels east-central Puerto Rico toward a knowledge-based economy. Caribbean Business newspaper, 25 August 2005, San Juan, Puerto Rico, USA.

Demographia World Urban Areas. March 2007. [online] URL:

http://www.demographia.com/db-worldua.pdf.

Elliott, J. R., and M. J. Perry. 1996. Metropolitanizing nonmetro space: population redistribution and emergent metropolitan areas, 1965-90. Rural Sociology 61:497-512.

Endress, B. A., and J. D. Chinea. 2001. Landscape patterns of tropical forest recovery in the Republic of Palau. Biotropica 33:555-565.

Ewel, J. J., and J. L.Whitmore. 1973. The ecological life zones of Puerto Rico and the U.S. Virgin Islands. Institute of Tropical Forestry, Rio Piedras, Puerto Rico. U.S. Forest Service Research Paper ITF-18.

Franco, P. A., P. L. Weaver, and S. EggenMcIntosh. 1997. Forest resources of Puerto Rico, 1990. Resource Bulletin SRS-22, U.S. Forest Service, Southern Research Station, Ashville, North Carolina, USA.

Gould, W. A., C. Alarcón, B. Fevold, M. E. Jiménez, S. Martinuzzi, G. Potts, M. Quiñones, 
M. Solórzano, and E. Ventosa. 2007. Puerto Rico gap analysis project - final report. U.S. Geological Survey, Moscow, Idaho and the U.S. Forest Service International Institute of Tropical Forestry, Río Piedras, Puerto Rico, USA.

Gould, W. A., B. Edwards, B. Fevold, and S. Martinuzzi. 2005. Fisiografía del Archipiélago de Puerto Rico. Map No. 2005-2. USDA Forest Service, International Institute of Tropical Forestry, Río Piedras, Puerto Rico, USA.

Grau, H. R., and T. M. Aide. 2007. Are rural-urban migration and sustainable development compatible in mountain systems? Mountain Research and Development 27:119-123.

Grau, H. R., T. M. Aide, J. K. Zimmerman, and J. R. Thomlinson. 2004. Trends and scenarios of the carbon budget in postagricultural Puerto Rico (1936-2060). Global Change Biology 10(7):11631179.

Grau, H. R., T. M. Aide, J. K. Zimmerman, J. R. Thomlinson, E. Helmer, and X. Zou. 2003. The ecological consequences of socioeconomic and land-use changes in postagriculture Puerto Rico. Bioscience 53:1159-1168. [online] URL: http://tce l.uprrp.edu/articulos/grau\%20et\%20al\%202003.pdf

Hecht, S. B., S. Kandel, I. Gome, N. Cuellar, and H. Rosa. 2006. Globalization, forest resurgence, and environmental politics in El Salvador. World Development 34:308-323.

Helmer, E. H. 2004. Forest conservation and land development in Puerto Rico. Landscape Ecology 19 (1):29-40.

Helmer, E. H., O. M. Ramos Gonzáez, T. del Mar López, M. Quiñonez, and W. Díaz. 2002. Mapping the forest type and land cover of Puerto Rico, a component of the Caribbean biodiversity hotspot. Caribbean Journal of Science 38(3-4):165-183.

Helmer, E. H., and B. Ruefenacht. 2005. Cloudfree satellite image mosaics with regression trees and histogram matching. Photogrammetric Engineering and Remote Sensing 71(9):1079-1089. [online] URL:

http://edcintl.cr.usgs.gov/macga/docs/Helmer.Ruef. PERS2005.pdf.
Johnson, M. P. 2001. Environmental impacts of urban sprawl: a survey of the literature and proposed research agenda. Environment and Planning $A \mathbf{3 3}$ (4):717-735.

Kahn, M. E. 2000. The environmental impact of suburbanization. Journal of Policy Analysis and Management 19(4):569-586.

Klooster, D. 2003. Regional forest transitions in highland Mexico? The importance of local institutions in a globalized countryside. Professional Geographer 55(2):227-327.

López, T. del M., T. M.Aide, and J. R. Thomlinson. 2001. Urban expansion and the loss of prime agricultural lands in Puerto Rico. Ambio 30:49-54.

Losada, H., H. Martinez, J. Vieyra, R. Pealing, and J. Cortés. 1998. Urban agriculture in the metropolitan zone of Mexico: changes over time in urban, sub-urban and peri-urban areas. Environment and Urbanization 10(2):37-54.

Lugo, A. E. 2002. Can we manage tropical landscapes? - an answer from the Caribbean perspective. Landscape Ecology 17:601-615.

Lugo, A. E., T. Del M. López, O. M. Ramos González, and L. L. Velez. 2004. Urbanización de los terrenos en la periferia de El Yunque. U.S. Forest Service Report WO-66.

Lugo, A. E., R. Schmidt, and S. Brown. 1981. Tropical forests in the Caribbean. Ambio 10:318324.

Martinuzzi, S., W. A. Gould, and O. M. RamosGonzález. 2007. Land development, land use, and urban sprawl in Puerto Rico integrating remote sensing and population census data. Landscape and Urban Planning 79:288-297.

McCune, B., and J. B. Grace. 2002. Analysis of ecological communities. MjM Software Design, Gleneden Beach, Oregon, USA.

Munroe, D., J. Clark, and E. Irwin. 2005. Regional determinants of exurban land use in the U.S. Midwest. Prepared for the 52nd Annual North American Meetings of the Regional Science Association, Las Vegas, Nevada, USA. 
Organisation for Economic Cooperation and Development (OECD). 1996. The knowledgebased economy. Paris, France. [online] URL: http:/ /www.oecd.org/dataoecd/51/8/1913021.pdf.

Read, L., D. Lawrence, and D. R. Foster. 2003. Recovery of biomass following shifting cultivation in dry tropical forests of the Yucatan. Ecological Applications 13:85-97.

Rivera, L. W., and T. M. Aide.1998. Forest recovery in the karst region of Puerto Rico. Forest Ecology and Management 108:63-75.

Rudel, T. K., D. Bates, and R. Machinguiasli. 2002. A tropical forest transition? Agricultural change, out-migration, and secondary forests in the Ecuadorian Amazon. Annals of the Association of American Geographers 92(1):87-102.

Rudel, T. K., O. T. Coomes, E. Moran, F. Achard, A. Angelsen, J. Xu, and E. Lambin. 2005. Forest transitions: towards a global understanding of land use. Global Environmental Change 15:23-31. [online] URL: http://webserver.sc.ucl.ac.be/GEO/L UCC/pdf/forest\%20transition\%20article.pdf.

Sánchez, T. W., and C. J. Dawkins. 2001. Distinguishing city and suburban movers: evidence from the American housing survey. Housing Policy Debate 12(3):607-631.

Shenjing, H. E., L. I. Zhigang, and W. U. Fulong. 2006. Transformation of the Chinese city, 19952005: geographical perspectives and geographers' contributions. China Information 20(3):429-456.

Thomlinson, J. R., and L. Rivera. 2000. Suburban growth in Luquillo, Puerto Rico: some consequences of development on natural and seminatural systems. Landscape and Urban Planing 49:15-23.

Thomlinson, J. R., M. I. Serrano, T. López, T. M. Aide, and J. K. Zimmerman. 1996. Land-use dynamics in a post agricultural Puerto Rican landscape (1936-1988). Biotropica 28:525-536. [online] URL: http://tcel.uprrp.edu/articulos/Thom linson,\%20J.R.\%20et\%20al.\%201996.pdf.

U.S. Census Bureau. 2001. Population change and distribution 1990 to 2000. Census 2000. Department of Commerce, Economics and Statistics Administration, Washington, D.C., USA. [online] URL: http://www.census.gov/prod/2001pubs/ c2kbr01-2.pdf.

van den Berg, L., R. Drewett, L. Klaassen, A. Rossi, and C. Vijverberg. 1982. A study of growth and decline. Pergamon Press, Oxford, UK.

Walker, R., S. Perz, M. Caldas, and L. G. Teixeira-Silva. 2002. Land use and land cover change in forest frontiers: the role of household life cycles. International Regional Science Review 25 (2):169-199.

Wassmer, R. W. 2002. Fiscalization of land use, urban growth boundaries, and non-central retail sprawl in the western United States. Urban Studies 39:1307-1327.

Zahawi, R.A., and C. K. Augspurger. 1999. Early plant succession in abandoned pastures in Ecuador. Biotropica 31:540-552.

Zhou, Y., and L. C. Ma. 2000. Economic restructuring and suburbanization in China. Urban Geography 21(3):205-236. 
APPENDIX 1. The six broad land-cover categories are based on detailed land-cover maps from 1991 (Helmer et al. 2002) and 2000 (Gould et al. 2007). This table shows the land-cover categories from the previous studies that were combined to create the broad categories used in the present study. Accuracy for the classification of major land-cover types has been assessed at 83\% and 85\% for the 1991 and 2000 maps respectively (Helmer et al. 2002, Gould et al. 2007).

\section{Reclassified land cover categories}

1991

2000
Lowland dry alluvial semidecidous forest

Lowland dry limestone semideciduous forest

Lowland dry limestone cliffside semideciduous forest

Lowland dry limestone volcanic semideciduous forest

Abandoned dry forest plantations

Lowland moist coconut palm forest

Lowland moist semi-deciduous forest

Lowland moist seasonal evergreen and semi-deciduous forest

Sub/lower montane wet evergreen sclerophyllous forest

Submontane wet evergreen forest

Lower montane wet evergreen forest/tall cloud forest

Lower montane wet evergreen forest - mixed palm and

elfin cloud forest

Lower montane wet evergreen forest - elfin cloud forest

Tidally and semi-permanently flooded evergreen
Lowland moist evergreen alluvial forest

Moist limestone evergreen and semideciduous forest

Moist limestone shrubland and woodland

Lowland moist evergreen volcanic forest

Lowland moist abandoned and active coffee plantations

Lowland moist riparian forest

Lowland dry riparian forest

Montane wet evergreen alluvial forest

Montane wet evergreen volcanic forest 
sclerophyllous forest

Seasonally flooded rainforest

Submontane and lower montane wet evergreen forest/ shrub and

active/abandoned coffee

Shrublands Lowland dry semideciduous woodland/shrubland

Lowland dry mixed evergreen deciduous shrubland with succulents

Lowland moist evergreen hemisclerophylous shrubland

Lowland moist seasonal evergreen forest/shrub

Lowland moist semi-deciduous forest/shrub

Lowland moist seasonal evergreen - semi-deciduous forest/shrub

Sub/lower montane wet evergreen sclerophyllous forest/ shrub

Active sun/shade coffee, sub/lower montane wet forest/ shrub

Tidally flooded evergreen dwarf-shrubland and forb vegetation
Montane wet evergreen Tabonuco forest

Montane wet evergreen Palo Colorado forest

Montane wet evergreen Sierra Palm forest

Montane wet evergreen elfin woodland cloud forest

Montane wet evergreen serpentine forest

Montane wet evergreen abandoned/active coffee plantations

Mangrove forest

Fresh water pterocarpus swamp

Lowland dry riparian shrubland and woodland

Lowland dry limestone woodland and shrubland

Lowland dry limestone shrubland

Lowland dry cactus shrubland

Lowland dry limestone cliffside shrubland and woodland

Lowland dryvolcanic shrubland and woodland

Coastal dwarf woodland and shrubland

Dry and moist serpentine woodland and shrubland

Lowland moist alluvial shrubland and woodland 
Lowland moist riparian shrubland and woodland

Lowland moist volcanic shrubland and woodland

Montane wet evergreen volcanic shrubland and woodland

Wet serpentine shrubland and woodland

Montane wet alluvial shrubland and woodland

Dry grasslands and pastures

Other emergent wetlands (including seasonally flooded pasture)

Agriculture Agriculture/hay

Agriculture

Urban area Urban and barren

Sand and Salt and mud flats Rock
Dry cactus grassland and shrublands

Emergent herbaceous nonsaline wetlands

Emergent herbaceous saline wetlands

Seasonally flooded herbaceous nonsaline wetlands

Seasonally flooded herbaceous saline wetlands

Woody agriculture and plantations

Aquiculture

Urban develpoment

Artificial barrens

Salt and mud flats 
Sand and Rock

Gravel and mixed sand beaches

Ripariand and other natural barrens

Rocky cliffs and shelves 